\title{
VERSITA
}

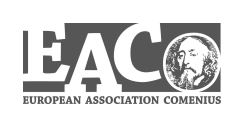

\section{Legal Rules on the Protection of Animals in Hungary}

\section{Anita Paulovics ${ }^{1}$}

\begin{abstract}
For centuries, man, as an important part of nature, has caused irreparable damage to its equilibrium. After the Second World War, it became clear that this process had led to the extinction of several species of animals. In spite of the importance of biodiversity, it only became an international, political concept after the Earth Summit in 1992. This was held in Rio de Janeiro, where the Agreement on Biodiversity was signed by many countries. Since then, biodiversity as a term has been widely used by politicians, the media, social organisations and others.

The European Union intends to validate strict requirements and provisions concerning animal protection. Most of these provisions have been legally validated in Hungary, but the country still lags behind in some respects. Further problems accrue as legal regulations concerning protected animals have been very hard to enforce in practice.

Overall, we can conclude that, in order to successfully protect animals, society should improve its way of looking at animals as a living part of nature. Without such an attitude, even the most perfect statutes cannot effectively ensure the protection of animals.
\end{abstract}

\section{Keywords}

Biodiversity, Endangered Animal Species, Nature Conservation, Animal Protection Act

\section{Introduction}

For centuries, man, as an important part of nature, has caused irreparable damage to its equilibrium. Forming nature according to its demands, mankind has continuously altered the natural equilibrium. After the Second World War, it was no longer just a theory that this process had led to the extinction of several species of animals. In spite of the importance of biodiversity, it only became an international, political concept after the Earth Summit in 1992. This was held in Rio de Janeiro, where the Agreement on Biodiversity was signed by many countries. Since then, biodiversity as a term has been widely used by politicians, the media, social organisations and others. Biodiversity means biological diversity in a given

\footnotetext{
${ }^{1}$ University of Miskolc, Faculty of Law, Egyetemváros, 3515 Miskolc, Hungary. E-mail: anijog@ freemail.hu.
} 
geographical area. Biodiversity concerns millions of species of animals and biodiversity of sufficient quality is an essential condition for life on earth. Diversity in the animal population provides a large number of goods and services that sustain our lives, such as food, clothing, synthetic materials and medicines. On the other hand, it should be the moral duty of humanity to protect nature and its beauty, diversity and value; none of which have unfortunately been paid enough attention. Although sometimes species of animals become extinct even without man being part of the cause, this used to be compensated for by the appearance of new species.

The extinction of animal species, however, has been as rapid in the last century as has not been the case since the extinction of the dinosaurs, 60 million years ago. One of the primary reasons for this fast extinction is the reduction of suitable conditions and habitats for animals, illegal animal trade, hunting, and the changing of the ecosystem not to mention the lack of environmental protection. Although the effects of this have not been directly felt by people, it could seriously endanger humanity. This is why it is especially important to pay respectful attention to animal protection as a special aspect of environmental protection. At the end of the 1990s, the European Community ran an overall survey on endangered animals in Europe. The survey points out that $50 \%$ of freshwater fish species living in Europe are threatened by extinction, while 50\% of frogs and reptiles, as well as $50 \%$ of mammals, are also endangered. Among other species, wolves, bears and dolphins are also on the list. According to experts at the University of Amsterdam, mankind would need at least 75 to 100 years to repair the ecological damages caused by deforestation.

This led to international co-operation concerning the protection of animals. Requirements that had been decided on at an international level were also included in national laws (as they were in Hungary, one of the countries that had signed the agreement). This method was a great step forward for animal protection. ${ }^{2}$

\section{Necessity of Legal Regulations Concerning Endangered Animal Species}

Animal species covered by nature conservation are not included in the animal protection act. ${ }^{3}$ The act, which came into force in $1996^{4}$, contains basic regulations relating to those species under conservation, while detailed regulations are written in the government decree of 1999. ${ }^{5}$ Special regulations concerning endangered species originate from the fact that regulations on these species appear in several international contracts. The protection of these endangered species is just as important in Hungary as in other countries. ${ }^{6}$

In order to claim protection for an animal, we should consider two factors. Both the value and the level of endangerment of the animal are important. Therefore, if an animal is valuable or endangered it should immediately be placed under protection. ${ }^{7}$ The term of

\footnotetext{
${ }^{2}$ For more details on the regulation, see Zoltán (1997).

3 Act XXVIII. 1998.

${ }^{4}$ Act LIII. 1996.

${ }^{5}$ See in detail, Zoltán (1997).

${ }^{6}$ See in detail, Zoltán (1999).

${ }^{7}$ Cf. Bánki (1988).
} 
protection can be described worldwide, by region, by country and locally. ${ }^{8}$ A species becomes legally protected by being pronounced as protected. When doing so, we have to pay special attention to those species that are either rare or are typical features of a given geographical area or country. A good example of such a protected animal in Hungary is the Greater Short-toed Lark. National features should be taken into account when pronouncing protection. In 2001, a ministerial regulation was put into effect that lists protected and highly-protected animals and (in a separate appendix) significant animals covered by the nature conservation of European Community. The mentioned regulation emphasises that anthills of nesting ants are protected because of their essential ecological role in nature. ${ }^{9}$ A separate appendix determines the value and the species of nesting ants under protection. This appendix also lists the protected and highly protected animals of Hungary and their value. There are species worth 1000 forints as well as species worth a million. A crop viper, a bald eagle or a great bustard are each worth a million forints. Among mammals, a lynx is the most valuable, at 500,000 forints. Species which have a significant role in nature conservation, according to the European Community, are listed in a separate appendix. In this appendix, we can find species that cannot be found in Hungary, such as the mountain viper. We can find a number of species of birds among the species pronounced as significant in the territory of the European Community, such as the Bonaparte's Gull and albatross. The number of mammals is not as high: this category includes the arctic fox.

People started to hunt down animals that could provide them with valuable trophies, meat, skin and bone; then they started to collect beautiful butterflies and beetles. But lately, environmental pollution has been causing more damage than the hunting, fishing and collecting of animals. Among the causes of some animals becoming extinct are the following: reduction of their natural habitat, hunting, animal trade, collecting animals and bird feathers, taxidermy, falconry, fishing or tourism. These human activities have been causing tremendous damage to the populations of some species. The destruction of the ecosystem also contributes to the problem, so that there is no longer any question as to why some species are disappearing. According to estimates, $99 \%$ of the species that once had lived on the Earth have disappeared. Mankind has speeded up the process of natural selection. ${ }^{10}$ Other species have become endangered. Before the Europeans settled, more than 100 million buffaloes lived on the American prairies. Settlers mostly killed the animals just to starve the Native Americans. Only a few of the buffalo survived this slaughter. There are only 360 buffaloes living in the Yellowstone National Park, which was founded in 1872 to protect endangered species like them. Most animals threatened by extinction live in America, Africa and Australia. One of the reasons for this desperate situation is that man has been trying to take over more land, destroying forests by cutting down trees, polluting the air and water, hunting and endangering native animals through the uncontrolled settlement of new species. Unfortunately, there are no species of animals

\footnotetext{
${ }^{8}$ Cf. Hinrichsen, Enyedi (1990).

${ }^{9}$ See in more detail, Kerekes, Kindler (1994).

${ }^{10}$ Cf. Bándi (1990).
} 
these days that are immune to becoming endangered or extinct. ${ }^{11}$ This is why it is very important for different organisations and representatives to exchange their experience on the protection of animals. Those species that have once become extinct or have disappeared in one country should be put under higher protection in other countries. The following features should be considered when trying to protect bigger animal groups. Restrictions should be made when giving permission to hunt down rare, valuable species that can provide trophies, such as the hippopotamus, elephant and rhinoceros.

'It is very difficult to determine the real cause of some animals becoming extinct we can only try to guess. ${ }^{12} 1800$ years ago, the bronco, moose and European buffalo became extinct. The protection of birds is one of the first projects in the history of protecting animals. For more than a century, national and international organizations have been monitoring the lifestyle, peregrination and reproduction of birds. Bird protection organisations should pay special attention to their habitats, nests and food supplies, as some species can easily adjust to changes, while some cannot. ${ }^{13}$

One of the most important parts of this protection is the feeding of the birds in winter. Regulations concerning bird protection list a total of 320 protected species of birds.

The protection of reptiles has lately been unfairly neglected in Hungary, although admittedly only 16 of the 6300 species living in the world live here. They are all protected, so fortunately none of them have become extinct or are threatened by extinction. Frogs have recently joined the list of those under protection. ${ }^{14}$ All of them are protected, but only the Alpine newt is endangered. There are 80 types of fish living in Hungary among 22,900 species worldwide. Two of the 80 species, such as the swamp fish, are endangered. The protection of invertebrate animals was also neglected for a long time in Hungary. In the 1970s, the first few - 170 species of butterflies - were put under protection by the Committee of Borsod County. Then in 1982, 153 species of invertebrates became protected all around the country, with their number rising to 397 so far.

Before reviewing the related government decree, we should mention that, even before the legislation of nature conservation laws, several animal species had been put under protection in Hungary. First, in 1901 the Minister of Agriculture claimed that 164 species were protected in total. The number of protected species started rising at the beginning of the 1900s. During this and later periods, it was primarily birds that were placed under protection. Today, 854 animals are under protection and 76 of them are highly protected. $3 \%$ of Hungary's animal population is under protection. 1901 was the year in which some endangered species - among them some species of bat - were pronounced to be highly protected. The number of species that are highly protected has been growing since 1950 . 26 out of the 81 species of fish living in Hungary are protected and there is one, the Danube Galoca, under high protection. All of the 16 species of amphibians are protected, although none of them are highly protected, while 2 out of the 15 species of reptiles enjoy high protection. 348 species of birds are protected out of the 373 living in Hungary and 70 of

\footnotetext{
${ }^{11}$ See in detail, Prugberger (2001).

12 Rakonczay (1998).

${ }^{13}$ See Waliczky (1992).

${ }^{14}$ Gubányi, Creemers (1994).
} 
them are highly protected. As we can see also above, most species of birds are protected in the country. There are 83 species of mammals in Hungary, 59 of them are protected and 11 are under high protection.

\section{Procedure for putting animals under protection}

The conservation of natural resources, with animals being an essential aspect of this, needs to be protected in order to be safe. The protection of different species of animals occurs after they are officially pronounced as protected. The process itself is very simple. The first step is to specify the species that are required to be put under protection. Then negotiations start between the owners and the organisations in charge. The next step is to adapt a protection resolution, which needs to contain the reason for the protection and what the important principles are. The authority is chosen according to the importance of the conservation value. If the resolution affects the whole country, the supreme nature conservation authority is in charge. If the natural resource is locally important, the local authority will become responsible. It is important to put the species under official protection, as only then can they become legally protected by law. We also have to mention grouped protection, which concerns the protection of several species of animals at the same time. In Hungary, this process has occurred only once so far, when, except a few species, most species of birds were put under protection by the same law. However, grouped protection should be very important, as most of the time separate protection is impossible or not as effective. Such a process would allow the bigger anthills to be put under legal protection. According to the local authority, the lack of any opportunity for grouped protection is the reason that only half of those species planned to be protected is actually put under legal protection.

In Hungary, the natural resources that are legally protected are listed in the "Natural Resources Conservation Register". Local resources are also registered and can be found in the Local or Regional Register. The system of nature conservation authorities is fairly different in each country. This is understandable if we look at the fact that there is only one international recommendation that provides the exclusive right for a country - and in the country only for the highest natural conservation authority - to establish natural parks.

\section{Long-Term Nature Conservation Program}

The National Nature Conservation Office approved a program called the Long-Term Nature Conservation Program in 1975, affecting the period 1976-1990. ${ }^{15}$ However, this program did not concern animal protection. Experts decided to publish these regulations in the socalled Red Books containing extinct, endangered and protected animals in order to raise public attention for the necessity of legal protection of certain species. The first Red Book came out in $1989 .{ }^{16}$ Reviewing protected animals is a continuous task and when taking animals into consideration, we should distinguish several categories. These categories are as follows:

\footnotetext{
15 Nováky, Hideg (1991).

${ }^{16}$ In more detail, Kenyeres, ifj. Tildy (1996).
} 
a) Species that have disappeared or became extinct

This category lists those animal species that have not been seen for 50 years, despite having been searched for regularly. These species need to be mentioned in case one of the specimens appears, so that it could immediately be put under protection, for example the sea eagle.

b) Highly endangered species

In this category, we mention those animals that live separately or in small animal populations. They have a good chance of becoming highly endangered by as a result of unfavourable changes in their living environment. A good example in this category is the black stork.

c) Endangered species

In this category, we list those species that live in small animal populations and whose habitat has started to decrease in size or change, for example the hawk.

d) Animals endangered in the long term

In this category, we can find those species that live in small populations separately and also those species that can be endangered by slight changes to their habitat, for example the rock eagle.

\section{Current regulations about protected species of animals}

After reviewing the categories, we should look into the current government decree concerning protected animals. The scope of the decree covers protected, highly protected species and their subspecies, variants as well as their living and dead species, forms and derivatives. It also covers those legal persons, organizations that keep, introduce or use protected or highly protected species of animals. Hybrids of a protected animal are also protected. The scope of the decree also covers species that were put under the force of an international natural conservation agreement, unless the statutes or nature conservation agreements dispose differently. Keeping, introducing and using listed protected animals requires official approval. An authority can only give permission if such permission is in accordance with the interests of nature conservation, does not endanger the animal population and furthermore public interest demands it. Approval for keeping, introducing and capturing protected animals is given by the Local National Park Directorate, while in the case of highly protected animals, the Ministry is entitled to give permission. There is no approval needed in the case of specimens that are listed in the second Appendix of the Washington Agreement and cannot be found in Hungary but whose importance had been legally established. ${ }^{17}$

Approval for keeping and introducing protected or highly protected animals should be given only for the following organizations for the public weal and only in the event that their activity serves the public interest and that they employ responsible people for the keeping and care of the animals:

${ }^{17}$ Cf. Láng (1999). 
- social organization,

- foundation,

- public foundation,

- company for the public weal,

- public corporation,

- other organizations for the public weal.

A legal person could only obtain permission to keep and introduce protected species of animals (except for falconry) in the event that the activity serves the public interest and the animals are taken care of properly by a well-trained person. Several affairs concerning this matter have become court cases. A plaintiff handed a request to the Local Authority for permission to keep a European wolf cub. The jury sustained the request and ordered the plaintiff to prepare a safe place for the animal and keep it locked up at all times. ${ }^{18}$ Later, the authority withdrew the permission and ordered the plaintiff to sell the animal to the Zoo and Plant Park of Budapest within 15 days..$^{19}$ The reason for this decision was that the plaintiff did not have approval from the Environmental Protection Authority. The authority of the second degree approved the decision. After observing and not finding the kennel and fence for the animal safe enough, the town clerk did not approve the claim, while the second degree authority did so. The town clerk instructed the authority to retract its permission, as during the period of this case, a new decree became effective stating that an animal that in any circumstance means danger to man is not allowed to be kept (even temporarily) within the borders of an administrative district. This put an end to the question and the claim was irrevocably denied by the authority of second degree. The plaintiff demanded auditing of the decision. The jury found the claim reasonable, because the denied permission infringed the plaintiff's rights and during the decision-making the cited regulation was not in effect.

Under these circumstances, the jury reversed the respondent's decision and ordered a new proceeding. Keeping and introducing protected and highly protected species of animals is, however, not allowed for a legal person even if they fulfil the dictated requirements. The statute demands strict requirements from the person in charge as well as from the legal person, in order to decide on the proper care of the protected or highly protected specimen. In order to fulfil these requirements, only the following people can be taken into consideration:

- a person of legal age and responsibility,

- a person with a clean record, who has not been charged with nature conservation felony followed by a contravention fee,

- a person with proper qualification, permission and experience in keeping animals.

The person taken into consideration can be a foreign citizen if he is a resident in Hungary and his country of origin verifies his skills and the abovementioned conditions he fulfils.

18 Cf. Zoltán (2000).

${ }^{19}$ About Zoo and Plant Park of Budapest, see Gall et al. (2001). 
Permission for falconry is given by a separately regulated nature conservation law. In this case the conditions concerning the matter are stricter than those mentioned above. A legal person can apply for permission for falconry only if he:

- meets the above requirements of a person to taken into consideration,

- is a member of the Hungarian National Chamber of Hunters,

- passes a nature conservation test in front of an examination board appointed by the Ministry,

- is able to provide the required terms of keeping an animal.

A legal person and an organization of the public weal are entitled to keep only two hunting birds and two couples for breeding. The Directorate of National Parks may give permission to keep a further two specimens to breed for nature conservation purposes or in case of injury to the animal. ${ }^{20}$ To keep or capture a protected or a highly protected bird for scientific purposes also demands legal permission. When requesting permission, applicants should make sure they attach proper research plans at all times. The plan should contain the names of the researchers and the people who are going to be responsible, the place and time as well as the target and method of the research. Permission is given by the Directorate of National Parks, or the Ministry in the event that there is more than one authority in charge of the decision. Only a person with the proper qualification and permission is allowed to ring a protected or highly protected bird or bat specimen for scientific or nature conservation purposes.

When giving permission to introduce an animal, the authorities have to make sure that the animal will be safe during the whole time of the introduction and that the proper conditions are upheld. Permission to introduce highly protected species of animals can only be given to organisations of the public weal founded exclusively for nature conservation purposes and which meet the prescribed terms. Protected animals or any of their specimens can only be, so to speak, used if the process does not endanger the subsistence and biodiversity of the animal population. In the case of highly protected species, this narrows down to only nature conservation purposes or public interest.

There are some court cases concerning the trade of protected or highly protected species of animals. In one case the plaintiff requested permission to keep and export buzzards that had been captured legally by hunters. The Directorate of National Parks refused to give permission since the capturing of an animal is not in the public interest, it is inconsistent with the purposes of nature conservation. The appeal of the plaintiff was refused by the second degree authority. The plaintiff asked for a review of the final decision. The jury granted the appeal as, according to them, the plaintiff had not requested permission to capture the buzzards, his interest was to keep and export them. Therefore it could not be determined whether it was for nature conservation purposes or not. The relevant statutes show provision for animals that had been legally captured and taken care of for the sake of nature conservation. According to the jury, the plaintiff's action served the purposes of nature conservation. The court quashed the decision and ordered the first degree administrative authority to initiate a new proceeding.

${ }^{20}$ Kenyeres, ifj. Tildy (1966). 
Nature conservation law also makes efforts to guarantee the special protection of protected animals. The law pronounces that any illegally obtained and owned natural resources need to be confiscated and distrained by the Directorate of National Parks. In the event that an animal deemed to be a natural resource under conservation is the property of the state, the conservationist authority is responsible of taking care of the animal until a decision is made by the authority in charge. Confiscated, protected natural resources - based on the nature conservation law - could only be used under the conditions of Government Ordinance. Detailed regulations concerning confiscated protected nature conservation resources are listed in a ministerial decree ${ }^{21}$. Provision of the regulations applies when the Directorate of National Parks or the Nature Conservation Authority or other authorities make decisions about placing, using or exterminating a confiscated specimen.

Confiscated protected natural resources are the property of Hungary. The authority that claims confiscation is responsible for making every provision necessary to protect the animal and its derivatives and pygmies. In the event that the authority claiming confiscation is not the Directorate or the ministry responsible for environment protection, the animal needs to be given immediately to the Directorate. Confiscated natural resources must only be used for nature conservation purposes in accordance with the terms of the specified regulations. While being confiscated and securely placed, a natural resource should not be involved in any kind of trade or become the property of a civil organisation or person. ${ }^{22}$ It is extremely important from the animal's point of view to make sure that the confiscated specimen is either placed back into its natural environment or used only for nature conservation purposes such as scientific studies or introductions. To fulfil the basic goals of the regulation and also for the sake of the resource, the animal should be returned to their natural habitat, and this needs to be done in every case where: ${ }^{23}$

- their origin is well-known,

- they are healthy and capable of living,

- placing them back to their natural environment does not have any disadvantages,

- after considering all circumstances the replacement promises success.

Authorities should be convinced of the following when assuring the conditions for returning the animal:

- while being captured and transported, the specimen did not contract any contagious infection that could affect other specimens,

- the animal does not belong to another subspecies but its own and does not originate from another place (in order to preserve genetic diversity),

- the animal does not carry the characteristics of another species as a result of the capture.

In the event that any of the abovementioned conditions apply, the animal should not be placed back into its natural environment but to an animal rescue institute. This institute

21 19/1997 (04.07.) KTM order.

22 See further Benkőné Lodner, (1988).

${ }^{23}$ Cf. Zoltán, (1992). 
may be a zoo, a wild animal park or a place for protected animals appointed and registered by the Ministry. In the event that the animal cannot for some reason be placed in any of the listed institutes, it can be placed in the private collection of a legal person under the proper conditions. The extermination of the animal may only be allowed if:

- returning it to its natural habitat is not recommended or possible, or placing it in an institution or private collection is not possible,

- the animal is suffering from an illness which cannot be cured and keeping it alive would be cruel and useless.

Therefore only in exceptional cases does the regulation allow the extermination of a specimen. The aim of the regulation is to place the animals back into their natural environment or in the best place available to make everything possible for them to survive and breed. Using the bodies of dead or over narcotized animals should only be allowed for nature conservation purposes and only for a nature conservation organisation, scientific, educational or research institution, public collection or an appointed legal person. If the conditions for using the animals within 6 months after confiscation do not apply and keeping the animal is highly expensive, then it should be exterminated to avoid illegal trade.

\section{Conclusion}

The European Union aims to validate strict requirements and provisions concerning animal protection. Most of these provisions have been validated legally in Hungary but the country still lags behind in some respects. Further problems accrue as legal regulations concerning protected animals have been very hard to enforce in practice.

Neither the administration of justice nor the legal terms had paid enough attention to animal protection before. There had not been enough demand for animal protection or environmental protection for years in Hungary. As part of the regulation of the environment protection, legal material concerning animal protection was only modernised about ten years after the political order changed. Since then, more and more civil organisations have accepted animal protection and its propagation as their duty. Still, society's opinion was divided even during the time of the preparation of new laws and jurisdictions on animal protection at the end of the 1990s. Fortunately, there have always been several civil groups which constantly fight for animal rights without being concerned as to how much money or effort it requires. Overall, we can conclude that, in order to succeed in animal protection, society should improve its way of looking at animals as part of living nature. Without such an attitude, even the most perfect statute is doomed to fail.

\section{References}

Bándi, Gy. (1991). Right to environment. In Katonáné Soltész, M. (ed.). Human rights in today's Hungary. Budapest: Mezon Kiadó.

Bánki, M. (1988). The place of legislation on the protection of the environment within the Hungarian legal system. In Tamás, A.; Lodner, D. (eds.). Environmental control and policy: Proceedings of the Hungarian - Polish Seminar on the theoretical problems of environmental control and policy. Pécs: Centre for Regional Studies. 
Benkőné Lodner, D. (1988). The legal regulation of nature conservation in the Hungarian People's Republic, with special regard to the conservation areas. In Tamás, A.; Lodner, D. (eds.). Environmental control and policy: Proceedings of the Hungarian - Polish Seminar on the theoretical problems of environmental control and policy. Pécs: Centre for Regional Studies.

Bochniarz, Z., Bolan, R., Kerekes, S., Kindler, J. (2003). Designing institutions for sustainable development in Hungary: Agenda for the future. Minneapolis - Budapest: Center for Environmental Studies.

Gall, A. et al. (2001). Ablak a természetre. Évszázadok állatkertje Budapesten. ("Window to Nature. A Century of the Budapest Zoo”). Budapest: Fóvárosi Állat és Növénykert.

Gubányi, A., Creemers, R. (1994). Population structure of water frogs in a foodplain of the river Dunabe in Hungary. Zoologica Poloniae. Vol. 39 (3-4), 441-445.

Hinrichsen, D., Enyedi, Gy. (1990). State of the Hungarian environment. Budapest: Statistical Publishing House.

Kenyeres, L., ifj. Tildy, Z. (1996). Védett természeti ritkaságaink. ("Protected Natural Resorts in Hungary”). Budapest: Mezőgazdasági Kiadó.

Láng, I. (1999). The environmental aspects of Hungary's EU accession. European Mirror, 4 (Special Issue), 46-57.

Nováky, E., Hideg, É. (1991). Developing environmental strategies: Through futures research. Budapest: Aqua Kiadó.

Prugberger, T. (2001). A globalizáció és a környezetvédelem neuralgikus kérdései a jogalkotás, a jogkövetés és a jogalkalmazás síkján. ("Problems in the law-making and application of law in environmental protection and globalisation"). Magyar Közigazgatás, 51 (10), 619-625.

Rakonczay, Z. (1998). Természetvédelem. ("Protection of Nature”). Budapest: Mezőgazdasági Szaktudás Kiadó.

Waliczky, Z. (1992). Európai jelentôségü madárélóhelyek Magyarországon. ("Bird Habitat of European Importance in Hungary”). Budapest: Magyar Madártani és Természetvédelmi Egyesület.

Zoltán, Ö. (1992). Az állatvédelem jogi szabályozásáról. (“The legal regulation of animal protection"). Magyar Jog, 39 (7), 401-405.

Zoltán, Ö. (1997). Az állatvédelmi törvény elé. ("Law on animal protection: Looking forward"). Magyar Jog, 44 (7), 407-415.

Zoltán, Ö. (1999). Az állatvédelmi törvény után. ("Law on animal protection: looking back”). Magyar Jog, 46 (4), 215-222.

Zoltán, Ö. (2000). Az állatvédelem jogi rendje. ("The legal regime of animal protection”). Budapest: Közgazdasági és Jogi Könyvkiadó.

Act XXVIII. of 1998 on the Protection of the Environment (General Rules), Hungary. Act LIII. of 1996 on Nature Conservation, Hungary.

19/1997 (04. 07.) KTM order on confiscated animals and plants under protection, Hungary. 